\title{
Taxonomic value of foliar characters in Dahlstedtia Malme - Leguminosae, Papilionoideae, Millettieae ${ }^{1}$
}

\author{
Simone de Pádua Teixeira ${ }^{2,4}$ and Antonio Carlos Gabrielli ${ }^{3}$
}

Received: April 4, 2005. Accepted: September 26, 2005

\begin{abstract}
RESUMO - (Valor taxonômico de caracteres foliares em Dahlstedtia Malme - Leguminosae, Papilionoideae, Millettieae). Dahlstedtia Malme (Leguminosae) é um gênero neotropical, com duas espécies reconhecidas, D. pinnata (Benth.) Malme e D. pentaphylla (Taub.) Burk., embora tenha sido considerado monotípico por alguns autores. Seus representantes ocorrem na Floresta Atlântica, nos Estados do Sul e Sudeste do Brasil. Neste trabalho, realizamos um estudo comparativo da anatomia foliar, para verificar a presença de caracteres que possam auxiliar a identificação das espécies. Primórdio foliar, lâmina foliar, peciólulo, pecíolo e pulvino foram coletados de plantas cultivadas em Campinas, SP, Brasil e de populações naturais encontradas em Picinguaba, Ubatuba e Caraguatatuba, SP, Brasil ( $D$. pinnata) e em Antonina, PR, Brasil (D. pentaphylla). Análises da superfície (Microscopia Eletrônica de Varredura), da venação foliolar e histológicas foram realizadas em material herborizado, fresco e fixado. A contagem de estômatos foi realizada após maceração do limbo. Lâminas semi-permanentes e permanentes foram confeccionadas com cortes obtidos a mão livre e em micrótomo rotativo, respectivamente, corados com Azul de Toluidina, Safranina/Azul de Alcian, Cloreto Férrico e Floroglucina Acidificada. Cavidades secretoras estão presentes na lâmina foliar, no peciólulo, no pecíolo, no pulvino e no primórdio foliar de D. pentaphylla, mas não foram encontradas em D. pinnata, constituindo um caráter diagnóstico para as espécies. Os outros caracteres foliares não foram informativos. Uma característica anatômica que merece ser ressaltada é a presença de atividade cambial no peciólulo, pecíolo e pulvino. Os dados obtidos deste estudo, associados a outros disponíveis na literatura, confirmam o reconhecimento de duas espécies no gênero Dahlstedtia.
\end{abstract}

Palavras-chave : atividade cambial, cavidades secretoras, Dahlstedtia pinnata, Dahlstedtia pentaphylla, parênquima paravenal

\begin{abstract}
Taxonomic value of foliar characters in Dahlstedtia Malme - Leguminosae, Papilionoideae, Millettieae). Dahlstedtia Malme (Leguminosae) is a neotropical genus, native to the Brazilian Atlantic Forest, and comprises two species, D. pinnata (Benth.) Malme and D. pentaphylla (Taub.) Burk., although it has been considered a monotypic genus by some authors. Leaf anatomy was compared to verify the presence of anatomical characters to help delimit species. Foliar primordium, leaflet, petiolule, petiole and pulvinus were collected from cultivated plants (Campinas, SP, Brazil) and from natural populations (Picinguaba, Ubatuba and Caraguatatuba, SP, Brazil - D. pinnata; Antonina, PR, Brazil - D. pentaphylla). Studies on leaflet surface assessment (Scanning Electron Microscopy), as well as histology and venation analyses were carried out of dehydrated, fresh and fixed material from two species. Leaflet material was macerated for stomatal counts. Histological sections, obtained by free-hand cut or microtome, were stained with Toluidine Blue, Safranin/Alcian Blue, Ferric Chloride, Acid Phloroglucin. Secretory cavities are present in the lamina, petiolule, petiole, pulvinus and leaf primordium in D. pentaphylla, but not in D. pinnata, and can be considered an important character for species diagnosis. Other leaf characters were uninformative in delimiting Dahlstedtia species. There is cambial activity in the petiolule, petiole and pulvinus. This study, associated with other available data, supports the recognition of two species in Dahlstedtia.
\end{abstract}

Key words: cambial activity, Dahlstedtia pinnata, Dahlstedtia pentaphylla, paraveinal mesophyll, secretory cavity

\section{Introduction}

The genus Dahlstedtia Malme (Leguminosae, Papilionoideae) belongs to tribe Millettieae (Geesink 1984), with two described species: D. pinnata (Benth.) Malme (type species) and D. pentaphylla (Taub.) Burk. Species descriptions are confused as regards floral morphology and even Burkart (1957), who recognized two species, cited specimens of one species under the other (see Malme 1905 and Burkart 1957). Some authors, such as Hutchinson (1964), Geesink (1981) and Vanni \& Rodríguez (1999) considered the genus monotypic.

Dahlstedtia species have been recorded from Brazil, especially the Atlantic Forest. Their representatives are shrubs or trees, with conspicuous

\footnotetext{
1 This work is part of the ms. thesis of the first author and was developed at Universidade Estadual de Campinas (Programa de Pós-Graduação em Biologia Vegetal).

2 Universidade de São Paulo, Faculdade de Ciências Farmacêuticas, Departamento de Ciências Farmacêuticas, Av. do Café, s/n, CEP 14040-903, Ribeirão Preto, SP, Brasil

3 Universidade Estadual de Campinas, Instituto de Biologia, Departamento de Botânica, C. Postal 6109, CEP 13083-970, Campinas, SP, Brasil

${ }^{4}$ Corresponding Author: spadua@fcfrp.usp.br
} 
papilionate flowers. The corolla of $D$. pinnata is pink and of $D$. pentaphylla reddish, besides the presence of conspicuous lenticels on the floral branches of $D$. pentaphylla and their absence in $D$. pinnata (Teixeira \& Gabrielli 2000).

The present study compared anatomically the leaves of D. pinnata and D. pentaphylla, to seek characters that can help distinguish between the species. These characters were then related to the other data available for the genus.

\section{Material and methods}

Foliar primordium, leaflet, petiolule, petiole and pulvinus of both species were collected from cultivated plants in Campinas, SP, Brazil. Material of Dahlstedtia pinnata from natural populations was collected at "the State Park of Serra do Mar", Picinguaba, Ubatuba and Caraguatatuba, State of São Paulo, Brazil and of D. pentaphylla at "Serra da Graciosa", Antonina, State of Paraná, Brazil. The vouchers are deposited in the Herbarium of Universidade Estadual de Campinas (UEC), São Paulo State, Brazil, under the numbers 28637, 28746, 300 and 17936.

The following herbarium material was studied: D. pentaphylla: M.L. Sekiama et al. 6610 (UEC), D.A. Great et al. 17 (UEC), N. Figueiredo et al. 14713 (UEC), P.H. Davis et al. 2934 (UEC); G. Arbócz 32707 (UEC).

D. pinnata: M.T.Z. Toniato et al. 30151 (UEC), H.F. Leitão Filho et al. 18745 (UEC), F.S. Santiago 25699 (UEC).

The material from herbarium specimens was treated according to Smith \& Smith (1942).

Whole leaflets were cleared and stained according to Berlyn \& Miksche (1976) modified by Monteiro et al. (1979) for venation studies.

Histological sections from herbarium specimens after treatment and from fresh material were stained with Toluidine Blue or Alcian Blue/Safranin and mounted in glycerin jelly. Fixed material was submitted to the standard techniques of infiltration with paraffin, stained with Safranin and Alcian Blue and the slides mounted in synthetic resin (Gerlach 1969).

To detect phenolic compounds and lignin, free hand sections were treated with Ferric Chloride and Acid Phloroglucin, respectively (Johansen 1940). The chemical composition of crystals was verified by $10 \%$ chloric acid, glacial acetic acid and sulfur acid (Chamberlain 1932 apud Arduin \& Krauss 1997).
Leaflet material was macerated following Jeffrey's method (Johansen 1940; Foster 1949) for stomatal counts. The Kolmogorov-Smirnov test was used (Zar 1996) to evaluate the significance of the difference found in the number of stomata/ $\mathrm{cm}^{2}$ of the foliolar lamina.

Photomicrographs were taken using a Zeiss II fotomicroscope and diagrams using a camera lucida.

Small pieces of leaflets were dehydrate in an ethanol series followed by critical-point drying in a Balzers CPD 030 apparatus; the specimens were mounted on aluminum stubs with colloidal carbon and coated with gold in a Balzers SCD 050 sputter coater for $280 \mathrm{~s}$. The samples were observed with a Jeol JSM 5200 scanning electron microscope at $15 \mathrm{kv}$, coupled with a Sinar 67 camera.

The terminology of Hickey (1973) was followed to describe the leaf architecture.

\section{Results}

The leaves are imparipinnate, alternate, pulvinate, with reduced or caducous stipules, opposite leaflets, 5-7-9 in D. pinnata and 5-7 in D. pentaphylla. The leaflets are symmetrical, narrowly elliptic, with attenuate apices, cuneate bases and entire margins (Fig. 1-2). Leaflet sizes vary from $9-13 \mathrm{~cm}$ long to $4-6 \mathrm{~cm}$ wide; the petiolule is $3-5 \mathrm{~cm}$ long; the petiole is $15-25 \mathrm{~cm}$ long; the rachis is $6,5-10,9 \mathrm{~cm}$ long and the pulvinus is $0,5-1,2 \mathrm{~cm}$ long. The larger sizes of leaf, petiolule, petiole, rachis and pulvinus were found in D. pinnata.

Leaflet surface is smooth in both adaxial (Fig. 3, 5) and abaxial sides (Fig. 4, 6), with wax deposits of

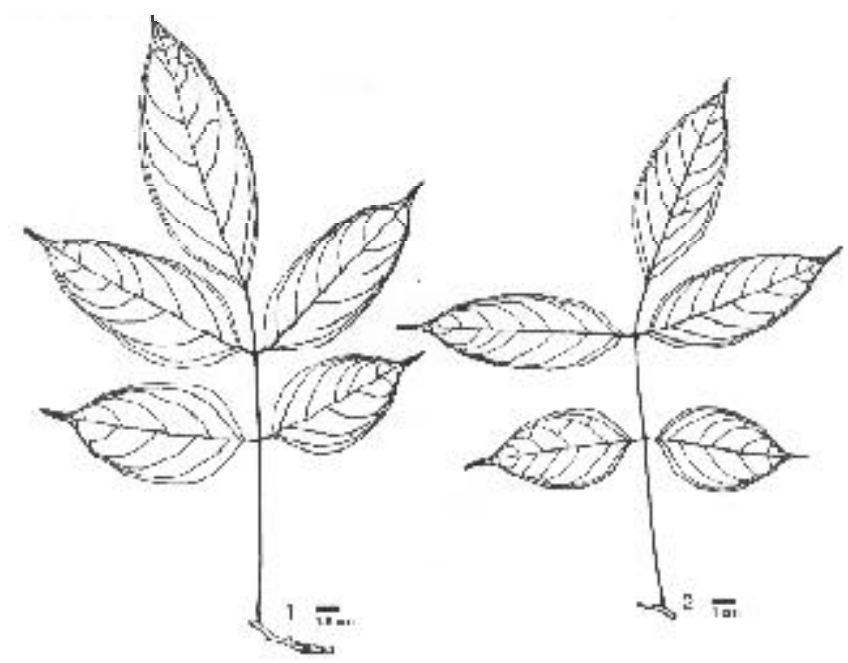

Figures 1-2. Leaf of Dahlstedtia Malme. 1. D. pinnata (Benth.) Malme. 2. D. pentaphylla (Taub.) Burk. 
several forms (Fig. 3-6). No trichomes are observed.

Venation is pinnate accompanied by brochidodromous secondary venation, with midvein of moderate size, following a straight, unbranched course (Fig. 7). The position of the first point of primary vein radiation is basal with moderate acute and nearly uniform angle of divergence (Fig. 1, 2, 7). Loop-forming branches of secondary veins join superjacent secondaries at moderate acute angles forming orthogonal reticulate pattern (Fig. 1, 2, 7). Secondary
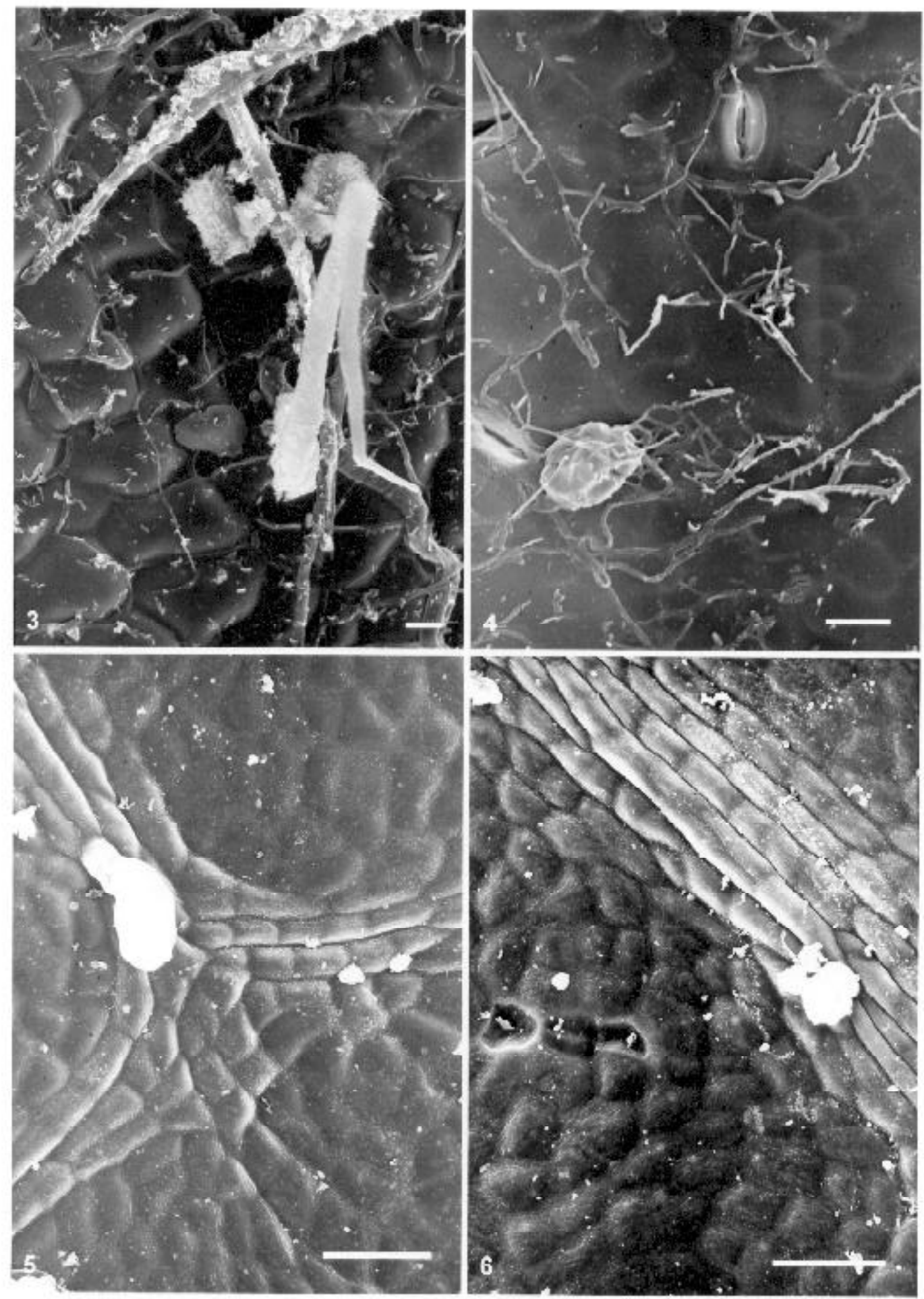

Figures 3-6. Leaflet surface of Dahlstedtia Malme species (MEV micrographs). Adaxial (3) and abaxial (4) sides of D. pinnata (Benth.) Malme. Adaxial (5) and abaxial (6) sides of D. pentaphylla (Taub.) Burk. Bars $=3,4=10 \mu \mathrm{m} ; 5,6=50 \mu \mathrm{m}$. 
veins follow a curved abruptly course (Fig. 7). Tertiary veins originating from secondary veins at right angles also form orthogonal reticulate pattern (Fig. 8, 9). The higher vein orders are distinct and also show orthogonal reticulate pattern (Fig. 8, 9). Ultimate veinlets branch once and the marginal ultimate venation is fimbriate (Fig. 8). Areoles are well-developed, pentagonal and large $(1-2 \mathrm{~mm})$ (Figs. 8, 9). Glands are present in $D$. pentaphylla (Fig. 9) and absent in D. pinnata.

Leaflet stomata are paracytic (Fig. 10) and occur only abaxially (Fig. 4). The number of stomata/ $\mathrm{cm}^{2}$ is $134 \pm 30$ (mean \pm standard deviation) for D. pentaphylla and $125 \pm 29$ (mean \pm standard deviation) for $D$. pinnata. The Kolmogorov-Smirnov test is $0,258 * * \mathrm{p}<<0,01$, indicating that the difference is significant.

Mesophyll is dorsiventral with approximately four layers (Fig. 11). The median layer has conspicuous spongy parenchyma cells (Fig. 11-12), with fewer chloroplasts than the other layers. These cells are horizontally enlarged; in paradermal sections, they are lobed and have conspicuous intercellular spaces (Fig. 12).

Secretory cavities (Fig. 9, 13-14) are only recorded for Dahlstedtia pentaphylla, and are characterized by a lumen surrounded by a one-layered epithelium. They are present in the palisade and bundle parenchyma in the whole leaflet lamina, in the cortical parenchyma of the petiolule and petiole, and in the peripheral parenchyma of the pulvinus (Fig. 14).

Secretory and tector trichomes occur throughout the epidermis at several developmental stages in the foliar primordium. The tector trichomes are uniseriate and falcate. The secretory trichomes (Fig. 13) vary in size, because the head can have four to six cells and the peduncle, two to three cells. The head cells have more evident nuclei, granular content and are more stained than the other trichome cells. No trichomes are present in the adult leaf.

The central bundle shape (Fig. 15-19) and the sclerenchyma structure (Fig. 15-19) vary along the foliar organs (Table 1). A vascular cambium (Fig. 20) is present in the petiolule, petiole and pulvinus (Table 1), originating a secondary structure in the vascular system. The xylem fibres increase in number and the rays are already formed (Fig. 21-22).

Crystalliferous and phenolic idioblasts occur along the leaf (Table 1). The crystals are prismatic (Fig. 23) and of calcium oxalate, and occupy the cell lumen almost completely. Both types of cells are very long, and form chains, when observed in longitudinal sections. Only in
Dahlstedtia pinnata crystalliferous idioblasts are located in the medulla of the petiole.

\section{Discussion}

In comparison with the vegetative axis (Teixeira $\&$ Gabrielli 2000), more useful characters are provided from leaves to distinguish between the two species of Dahlstedtia. The presence of secretory cavities in $D$. pentaphylla and their absence in D. pinnata was an important character for diagnosis of the species (Table 2). Secretory cavities were similarly located in all the examined representatives of $D$. pentaphylla, and they are an easily observed character for species identification with the use of free hand sections. Clarified leaflets should be used carefully, because the presence of conspicuous spaces in the mesophyll of D. pinnata may be confused with glandular punctuations, as in Brazilian Lonchocarpus Kunth. species (Teixeira et al. 2000).

Secretory cavities have already been observed in the leaves of genera related to Dahlstedtia, such as Lonchocarpus and Derris Lour. (Solereder 1908; Metcalfe \& Chalk 1950; Teixeira et al. 2000), and they have been studied in detail in tribes Amorpheae and Psoraleae (Turner 1986), and cited in Poiretia Vent. (Müller unpublished), Zornia J.F. Gmel. (Kothari \& Shah 1975), Myrocarpus frondosus Allemão, Myroxylon peruiferum L. f. (Freire 1984) and Poincianella Britton \& Rose (Lersten \& Curtis 1994). Secretory structures have been used in taxonomic studies due to their variety of morphological types and their constant position in the plant body and taxon analyzed (Solereder 1908; Metcalfe \& Chalk 1950; Fahn 1979). In legumes, secretory cavities were used, at subgeneric level, to define a group of species in Poincianella (Lersten \& Curtis 1994) and at suprageneric level, to maintain the "status" of tribes Amorpheae and Psoraleeae (Turner 1986).

Other leaf characters deserve comments: the number of stomata and the distribution of crystalliferous idioblasts. The differences found in the stomata number $/ \mathrm{cm}^{2}$ between the two species of Dahlstedtia were significant (Kolmogorov-Smirnov test). Despite the similarity of the morphology and type of crystal between species, there was difference in the distribution of crystalliferous idioblasts in the petiole (Table 2). Therefore, these characters may also be informative for the delimitation of these species.

The presence of glandular trichomes and idioblasts containing phenolic compounds is a similarity in both 


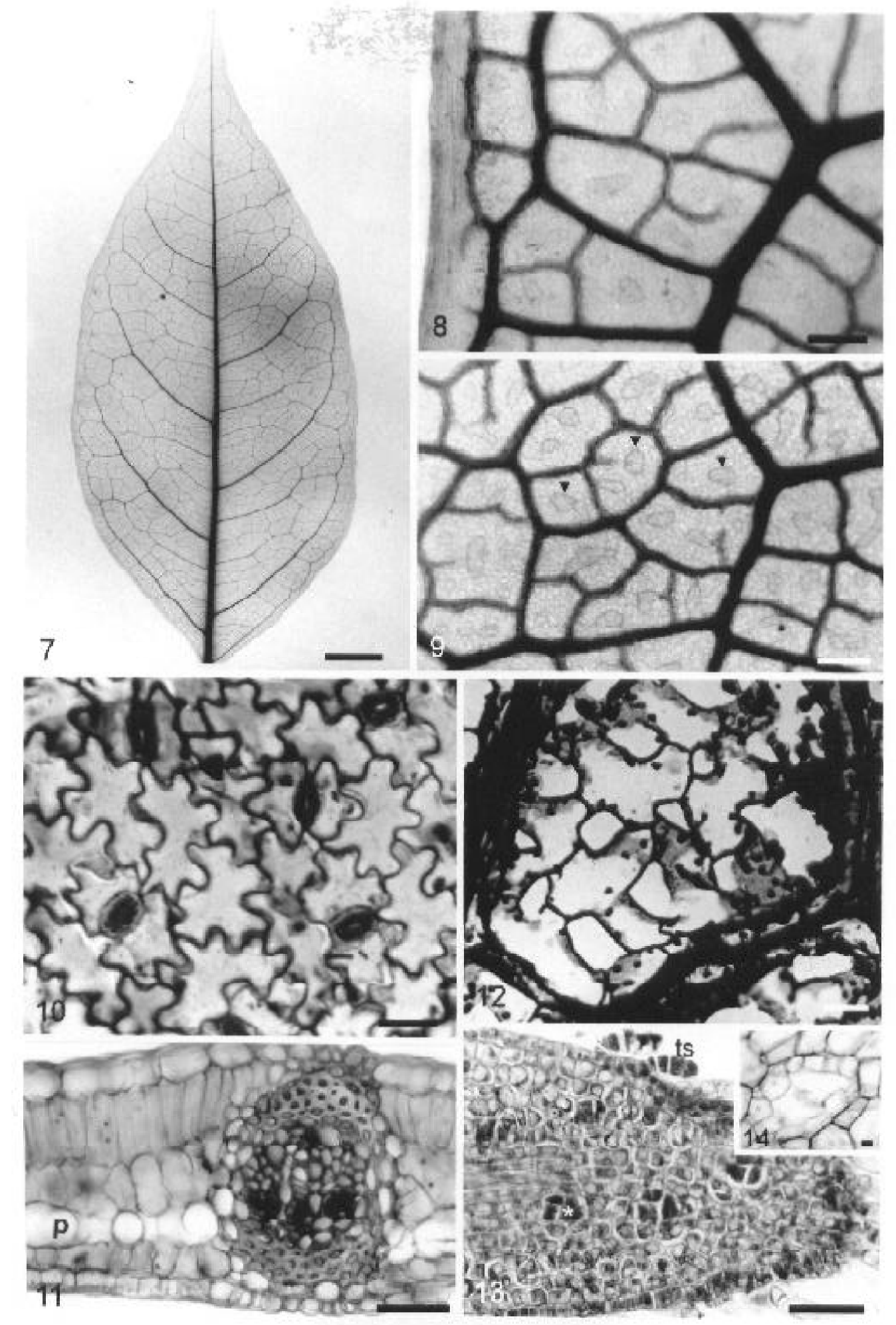

Figures 7-14. Venation pattern and leaf anatomy of Dahlstedtia pentaphylla (Taub.) Burk. 7. Brochidodromous venation type. Note the straight unbranched course of the midvein and the secondary vein loops. 8. Marginal ultimate venation (fimbriate). 9. Well-developed areoles and glandular dots (arrows). Note the tertiary veins forming orthogonal reticulate pattern. 10. Frontal view of epidermis (abaxial side) showing paracytic stomata. 11. Transverse section of leaf lamina showing dorsiventral mesophyll and a secondary bundle. Note the median layer of the mesophyll (p) - paraveinal mesophyll. 12. Paraveinal mesophyll. 13. Early developmental stage of the secretory cavity (*) and of the secretory trichomes (ts) in a leaf primordium. 14. Transverse section of pulvinus showing a secretory cavity. Bars $=7=1 \mathrm{~cm} ; 8-9=500 \mu \mathrm{m} ; 10,12=14 \mu \mathrm{m} ; 11=30 \mu \mathrm{m} ; 13=20 \mu \mathrm{m} ; 14=50 \mu \mathrm{m}$. 

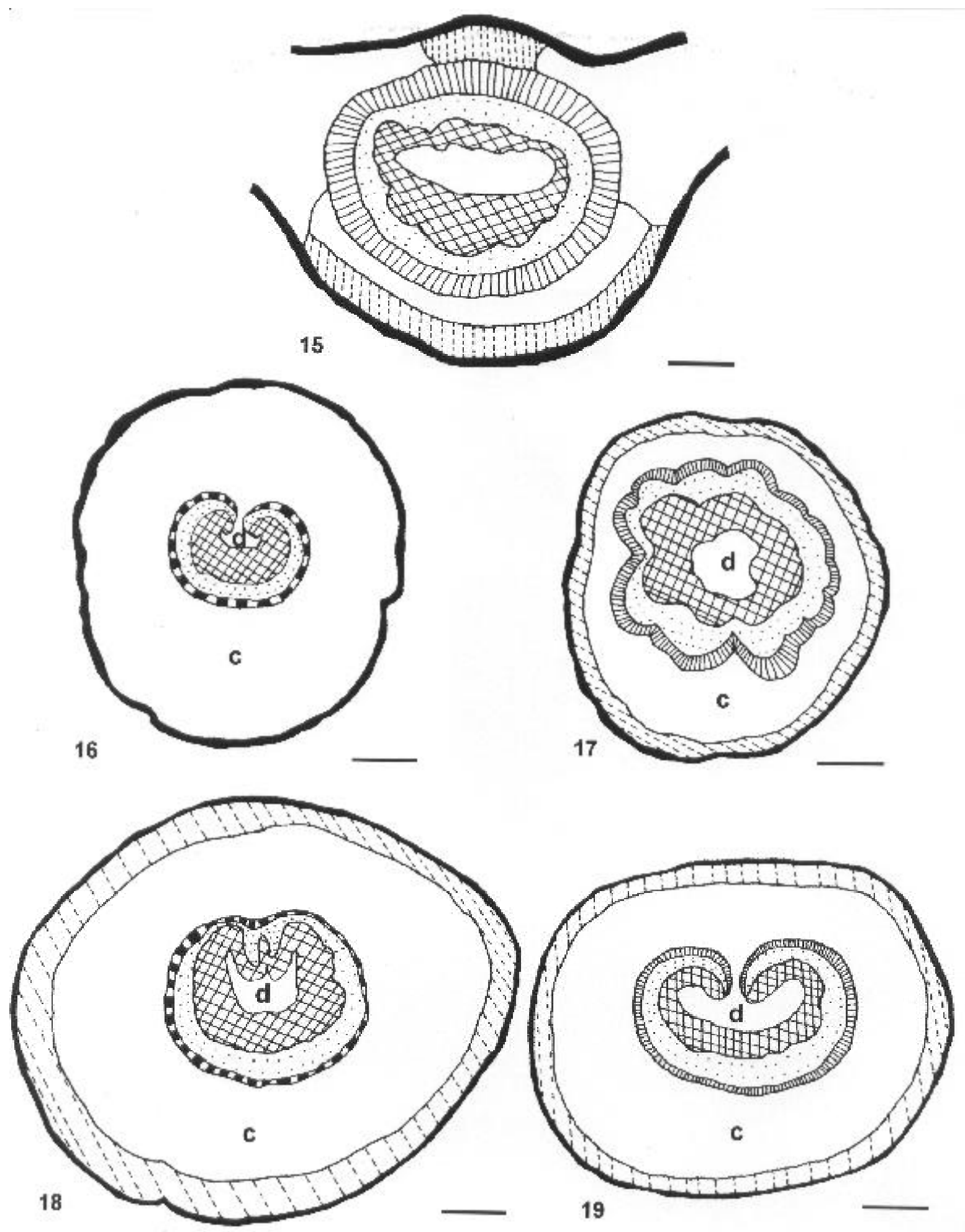

Figures 15-19. Transverse sections of the vascular system and other tissues in Dahlstedtia pentaphylla (Taub.) Burk. leaves. 15. Midrib of the foliar lamina. 16. Petiolule. 17. Petiole. 18. Upper half of pulvinus. 19. Lower half of pulvinus. (hatched - epidermis; white - parenchyma; dashed - collenchyma; strongly striped - schlerenchyma densely stained by Safranin; striped - schlerenchyma weakly stained by Safranin; cross-hatched - xylem; dotted - phloem). Abbreviations: c - cortical parenchyma, d - medullar parenchyma. Bars $=15=125 \mu \mathrm{m} ; 16=500 \mu \mathrm{m} ; 17-19=200 \mu \mathrm{m}$. 
Table 1. A comparison of anatomic characteristics in the leaf lamina, petiolule, petiole and pulvinus of Dahlstedtia Malme species.

\begin{tabular}{|c|c|c|c|c|c|}
\hline Leaf parts & Central bundle shape & Sclerenchyma & $\begin{array}{l}\text { Cambial } \\
\text { activity }\end{array}$ & $\begin{array}{l}\text { Distribution of } \\
\text { crystalliferous } \\
\text { idioblasts }\end{array}$ & $\begin{array}{c}\text { Distribution of } \\
\text { phenolic idioblasts }\end{array}$ \\
\hline Leaf lamina & closed (Fig. 15) & $\begin{array}{l}\text { ring of lignified } \\
\text { fibres (Fig. 15) }\end{array}$ & - & $\begin{array}{l}\text { parenchyma tissue } \\
\text { of the larger bundles }\end{array}$ & $\begin{array}{l}\text { among the phloem } \\
\text { parenchyma cells and the } \\
\text { central bundle }\end{array}$ \\
\hline Petiolule & $\begin{array}{l}\text { open with curved } \\
\text { edges (Fig. 16) }\end{array}$ & $\begin{array}{l}\text { ring of gelatinous } \\
\text { fibres (Fig. 16) }\end{array}$ & + & $\begin{array}{l}\text { subepidermal cells } \\
\text { in the perivascular tissue }\end{array}$ & $\begin{array}{l}\text { among the phloem } \\
\text { and central } \\
\text { parenchyma cells }\end{array}$ \\
\hline Petiole & closed (Fig. 17) & $\begin{array}{c}\text { grooves of } \\
\text { lignified fibres (Fig. 17) }\end{array}$ & + & $\begin{array}{l}\text { among the collenchyma } \\
\text { and the parenchyma }\end{array}$ & $\begin{array}{l}\text { among the phloem and } \\
\text { central parenchyma cells }\end{array}$ \\
\hline $\begin{array}{r}\text { Pulvinus upper half } \\
\text { lower half }\end{array}$ & $\begin{array}{c}\text { closed and } \\
\text { very grooved (Fig. 18) } \\
\text { open and } \\
\text { enlarged (Fig. 19) }\end{array}$ & $\begin{array}{l}\text { arc of lignified fibres } \\
\text { (Fig. 18-19) }\end{array}$ & + & $\begin{array}{l}\text { subepidermal and } \\
\text { perivascular tissues }\end{array}$ & phloem parenchyma cells \\
\hline
\end{tabular}
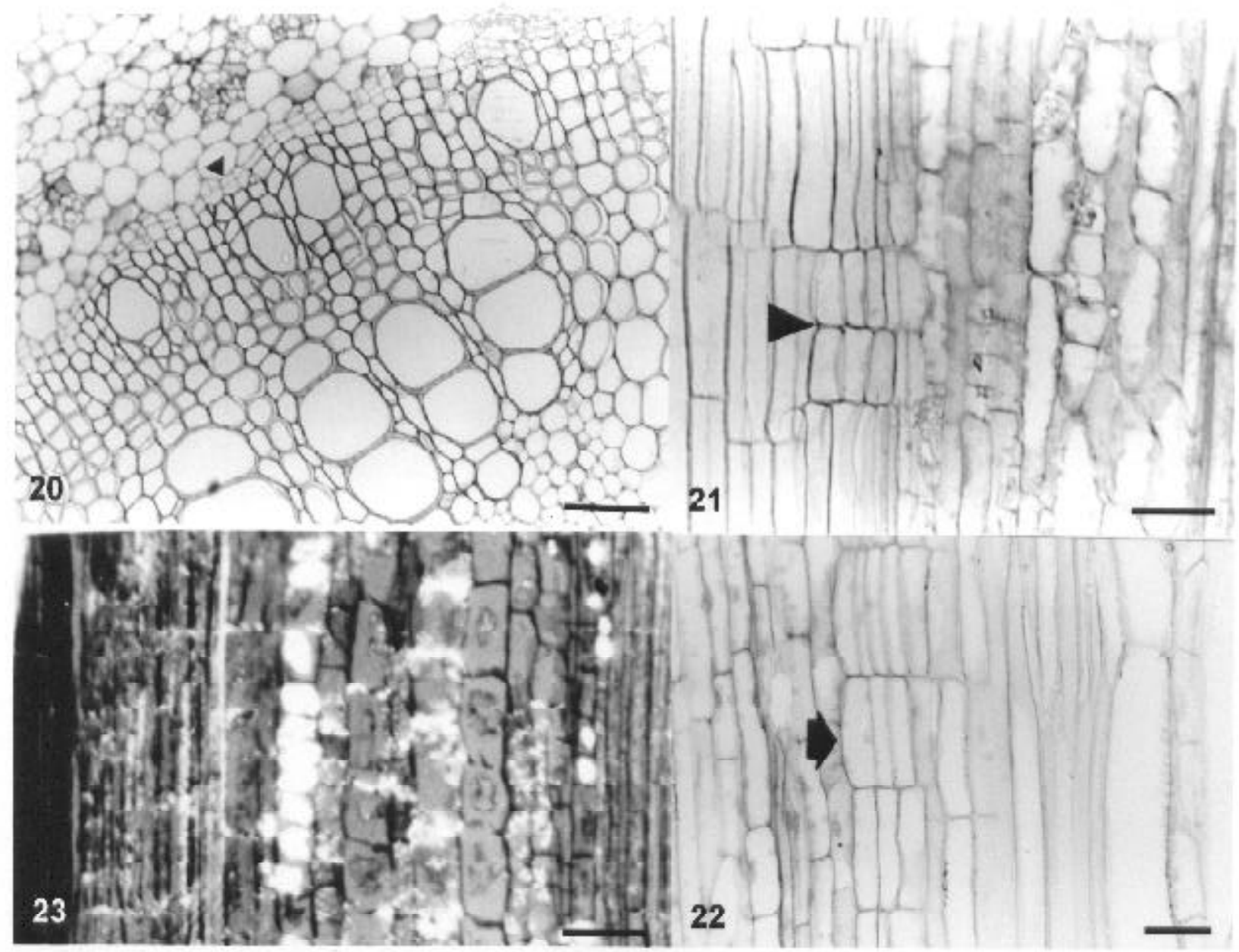

Figures 20-23. Cambial activity in the leaf of Dahlstedtia pinnata (Benth.) Malme. 20. Transverse section of the petiole. Note the cambial activity (arrow). 21. Longitudinal section of the petiole showing parenchyma rays (arrow). 22. Radial section of the petiolule showing parenchyma rays (arrow). 23. Radial section of the petiole showing crystalliferous idioblasts (semi-polarized light). Bars $=20=43 \mu \mathrm{m} ; 21-23=22 \mu \mathrm{m}$. 
Table 2. Leaf and other available data of the Dahlstedtia Malme species.

\begin{tabular}{llll}
\hline Organ studied & \multicolumn{1}{c}{ D. pinnata } & D. pentaphylla & Author(s) \\
\hline Flower & Upright inflorescence & Hanging inflorescence & Teixeira \& Gabrielli 2000 \\
& Purple corolla & Geranium corolla & Malme 1905; Burkart 1957 \\
Leaf & Secretory cavities absent & Secretory cavities present & Present study \\
& $\begin{array}{l}\text { Crystalliferous idioblasts absent } \\
\text { in the centre of the petiole }\end{array}$ & $\begin{array}{l}\text { Crystalliferous idioblasts } \\
\text { in the centre of the petiole }\end{array}$ & Present study \\
Shoot & Secretory cavities absent & Secretory cavities present & Teixeira \& Gabrielli 2000 \\
& in the shoot apex & in the shoot apex & Teixeira \& Gabrielli 2000 \\
& Crystalliferous idioblasts absent & Crystalliferous idioblasts & Teixeira \& Gabrielli 2000 \\
& in the phloem and medulla & present in the phloem and medulla & Sclenchymatous ring six-layered \\
Sclerenchymatous ring one & to two-layered & Tetrarc apical root & Teixeira \& Gabrielli 2000 \\
\hline
\end{tabular}

species as are the characteristics of dorsiventral mesophyll, hypostomatic leaflet and paracytic stomata.

The vascular system of the pulvinus, the petiole, the petiolule and the leaf lamina (see Fig. 15-19) are similar in $D$. pinnata and $D$. pentaphylla, although the vascular system patterns of the petiole in Leguminosae are variable at tribal, generic or specific level (Watari 1934; Dormer 1945). The petiole of Dahlstedtia is hold by the medium and lateral traces, while the stipules are hold by the lateral ones.

The median layer of the mesophyll observed in Dahlstedtia is similar to a very developed spongy parenchyma. Morphologically, this tissue can be compared to the paraveinal mesophyll (Fisher 1967) or extended bundle sheath system, the most recent designation (Kevekordes et al. 1988). The extended bundle sheath system has already been described in 52 legume species (Kevekordes et al. 1988) and characterized as one-layered, horizontally displayed and with lobed cells that occur between the spongy and palisade parenchyma (Solereder 1908; Metcalfe \& Chalk 1950; Fisher 1967), of procambial origin (Weston \& Cass 1973). Despite the morphological similarity, this tissue deserves developmental studies to clarify its origin in Dahlstedtia.

Cambial activity in the petiolule, petiole and pulvinus of Dahlstedtia species was confirmed by the presence of a radial structure observed in radial sections. Most reports of cambial activity in leaves refer to Gymnosperms (Mauseth 1988). The few dicotyledon species presenting cambial activity in the leaves, Laurocerasus officinalis Roem., Ligustrum vulgare L., Ulmus montana With. and Viburnum rhythidophyllum Hemsl., were studied by Shtromberg (1959).
This leaf anatomical study, associated to other available data (see table 2), agrees with Burkart's taxonomic position (1957), according to which Dahlstedtia comprises at least two species: $D$. pinnata and D. pentaphylla.

\section{Acknowledgements}

The first author is grateful to CAPES, for research financial support; thank Dr. Volker Bittrich for his helpful comments on the manuscript and the English review, Sebastião Henrique Militão Jr. (Plant Anatomy Lab/IB, UNICAMP), Maria Dolores Seabra Ferreira and José Augusto Maulin (TEM Laboratory/BCMBP, FMRP-USP), for technical assistance.

\section{References}

Arduin, M. \& Krauss, J.E. 1997. Manual Básico de Técnicas em Anatomia Vegetal. Rio de Janeiro, Edur.

Berlyn, G.P. \& Miksche, J.P. 1976. Botanical microtechnique and cytochemistry. Ames, The Iowa State University Press.

Burkart, A. 1957. Dahlstedtia pinnata (Taub.) Burk., nov. comb. Darwiniana 11: 269.

Dormer, K.J. 1945. An investigation of the taxonomic value of shoot structure in Angiosperms with special reference to Leguminosae. Annals of Botany 9: 141-153.

Fahn, A. 1979. Secretory Tissues in Plants. New York, Academic Press.

Fisher, D.B. 1967. An unusual layer of cells in the mesophyll of the soybean leaf. Botanical Gazette 128: 215-218.

Foster, A.S. 1949. Practical Plant Anatomy. New York, Van Hostrand.

Freire, S.F. 1984. Anatomia foliar de las especies argentinas de la tribu Sophoreae, excepto Adesmia (Leguminosae, Papilionoideae). Darwiniana 25: 123-142. 
Geesink, R. 1981. Tephrosieae (Benth.) Huch. Pp. 245-260. In: R.M. Polhill \& P.H. Raven (eds.). Advances in Legume Systematics. Kew, Royal Botanic Gardens.

Geesink, R. 1984. Scala Millettiearum. A survey of the genera of the tribe Millettieae (Leguminosae, Papilionoideae). E.J. Brill \& Leiden University Press. (Leiden Botanical Series, 1).

Gerlach, G. 1969. Botanische Mikrotechnik, eine Einfuhrung. Stuttgard, Gorg Thieme.

Hickey, L.J. \& Wolfe, J.A. 1975. The bases of Angiosperm Phylogeny: Vegetative Morphology. Annals of Missouri Botanical Garden 62: 538-589.

Hutchinson, J. 1964. The genera of flowering plants (Angiospermae) - Dicotyledons, v.1. Oxford, Clarendon Press.

Johansen, D.A. 1940. Plant Microtechnique. New York, McGraw-Hill Book Company Inc.

Kevekordes, K.G.; McCully, M.E. \& Canny, M.J. 1988. The occurrence of an extended bundle sheath system (paraveinal mesophyll) in the legumes. Canadian Journal of Botany 66: 94-100.

Kothari, M.J. \& Shah, G.L. 1975. Epidermal structures and ontogeny of stomata in the Papilionaceae (tribe Hedysareae). Botanical Gazette 136: 372-379.

Lersten, N.R. \& Curtis, J.D. 1994. Leaf anatomy in Caesalpinia and Hoffmannseggia (Leguminosae, Caesalpinioideae) with emphasis on secretory structures. Plant Systematics and Evolution 192: 231-255.

Malme, G. 1905. Dahlstedtia, eine neue Leguminosen Gattung. Arkiv Botanische 4: 1-7.

Mauseth, J.D. 1988. Plant Anatomy. Menlo Park, The Benjamin Cummings Publishing Company.

Metcalfe, C.R. \& Chalk, L. 1950. Anatomy of the Dicotyledons: leaves, stem and wood in relation to taxonomy with notes one economic uses. v.1. Oxford, Clarendon Press.
Monteiro, W.R.; Giulietti, A.M.; Mazzoni, S.C. \& Castro, M.M. 1979. Hairs on reproductive organs of some Eriocaulaceae and their taxonomic significance. Boletim de Botânica da Universidade de São Paulo 7: 43-59.

Shtromberg, A. 1959. Cambial activity in leaves of some woody dicotyledons. Doklady Botanical Sciences Sections (Doklady Akademii Nauk SSSR) 124: 699-702.

Smith, F.H. \& Smith, E.C. 1942. Anatomy of the inferior ovary of Darbya. American Journal of Botany 29:464-471.

Solereder, H. 1908. Systematic anatomy of the Dicotyledons. A handbook for laboratories of pure and applied Botany. Translated by L.A. Boodle \& F.G. Fritsch, v.1. Oxford, Clarendon Press.

Teixeira, S.P. \& Gabrielli, A.C. 2000. Anatomia do eixo vegetativo de Dahlstedtia pinnata (Benth.) Malme e D. pentaphylla (Taub.) Burkart (Leguminosae, Papilionoideae). Brazilian Journal of Botany 23: 1-11.

Teixeira, S.P.; Castro, M.M. \& Tozzi, A.M.G.A. 2000. Secretory cavities and pellucid dots in leaflets of Lonchocarpus (Leguminosae, Papilionoideae, Millettieae). Plant Systematics and Evolution 221: 61-68.

Turner, G.W. 1986. Comparative development of secretory cavities in the tribes Amorpheae and Psoraleeae (Leguminosae: Papilionoideae). American Journal of Botany 73: 1178-1192.

Vanni, R.O. \& Rodríguez, M. 1999.Dahlstedtia (Leguminosae, Millettieae) nueva cita para la flora argentina. Hickenia 3: 5-8.

Watari, S. 1934. Anatomical studies on some Leguminous leaves with special reference to the vascular system in petioles and rachises. Journal of the Faculty of Science, Imperial University of Tokyo 3: 225-369.

Weston, GD. \& Cass, D.D. 1973. Observations on the development of the paraveinal mesophyll of soybean leaves. Botanical Gazette 134: 232-235.

Zar, J.H. 1996. Biostatistical analysis $3^{\text {rd }}$ ed. New Jersey, Prentice Hall. 